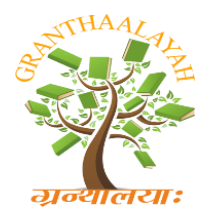

INTERNATIONAL JOURNAL OF RESEARCH GRANTHAALAYAH

A knowledge Repository

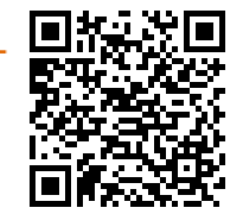

Management

\title{
A STUDY ON CUSTOMER SATISFACTION TOWARDS SAKTHI MASALA PRODUCTS IN SALEM DISTRICT
}

\author{
Dr. M.Rajamanickam ${ }^{* 1}$ MBA Ph.D \\ ${ }^{* 1}$ Associate Professer in MBA, CMS College of Engineering, Namakkal, INDIA
}

\begin{abstract}
SAKTHI MASALA" the Queen of spices as the household name among the millions today, it was doing Turmeric trading for some time. Later entered into the arena of pure spice powders like Turmeric, Chilli and Coriander. This inquisitiveness lets to enter into masala world with boldness. This masala encountered a lot of hurdles, since selling masala powders during those days to the oriental women who are traditionally conservative; it was not easy to sell. It was concept sealing on "Easy Cooking" rather than marketing food products with selfdetermination and persistent attempts it was able to get into the kitchens of our country and the rest of the world. The store may look like a miracle, but the hard work, the pot holes and the bumps on the way and the stormy inclement weather are known only to producer. The person who stood behind produce masala for all those achievement was with help of their business partner.
\end{abstract}

Keywords:

Sakthi Masala, Product, Powder, food, Cooking.

Cite This Article: Dr. M.Rajamanickam, "A STUDY ON CUSTOMER SATISFACTION TOWARDS SAKTHI MASALA PRODUCTS IN SALEM DISTRICT” International Journal of Research - Granthaalayah, Vol. 4, No. 5: SE (2016): 113-119.

\section{INTRODUCTION}

Sakthi masala was small turmeric trader, from a village called perundurai near Eroad. He founded SAKTHI TRADING COMPANY in 1975. Now SAKTHI MASALA manufactures over 50 varieties of Spice and Masala powder, over a dozen varieties of Pickles, Appalams, ghee and sunflower oil. Sakthi Masala gives value addition to the agricultural product which helps and encourages the farming community to market their products also generates lot of employment opportunities to the agriculture labours and rural people. The company employs mostly women and differently able persons from the rural areas and makes them to lead an honorary life. The company has bagged with IS/ISO 9001:2008 certification from Bureau of Indian standards, New Delhi. 
The customers of SAKTHI MASALA are the house wives and those who want quick and easy cooking solution, restaurants, hotels, canteens are the other consumers. SAKTHI MASALA reaches the houses located in the nook \& corner of the country through its strong marketing network.

Success of SAKTHI MASALA lies in the innovation of manufacturing procedures, as there were no definite machineries for specific production of spice and spice mixes with the growing experience suitable changes were made to suit the requirement that made. all the difference in manufacturing spice powders and spice mixes which retains the aroma and flavor.

\section{NEED FOR THE STUDY}

Most of the companies want to know about the customer satisfaction, because normally they had made a huge amount of investment to make the product known to the customers. In order to know the effectiveness of sales and customer satisfaction can be made through the particular survey.

If the customers are not satisfied they would switch over to the other products it is very difficult to bring back those customers to make purchase and encourage them to make a word of mouth

\section{OBJECTIVES OF THE STUDY}

1) To find out the opinion of the consumers of Sakthi Masala products.

2) To analyze the factors that affects the purchasing patterns of the consumer in Sakthi Masala products in SALEM District.

3) To find out the customer satisfaction level of taste, price, quality, availability, durability of Sakthi Masala products.

4) To analyze the most effective media of advertisement

5) To offer suggestions to improve the customer satisfaction of Sakthi Masala products, Some Common Mistakes.

\section{RESEARCH METHODOLOGY}

\subsection{RESEARCH DESIGN}

\section{Descriptive Research Design}

This research which design was adopted for this study is exploratory and descriptive design. This project is designed to identify the factors which influence the customers and the ways through which to choose or to buy Sakthi Masala product in SALEM District.

The objective of descriptive study is to learn that who want, when, where and how of the topic. The study may be simple or complex, it may be done in many setting. The simplest descriptive study concerns an invariant question or hypothesis in which we ask about, or state something about the size, form, distribution, or existence of variable. 
Descriptive studies may involve the collection of data and the creation of a distribution of the number of time the researcher observes a single event or characteristics or they may involve relating the interaction of two or more variables. Descriptive studies may or may not have the potential for drawing powerful inferences. The descriptive study is popular in business research because of its versatility across disciplines.

\subsection{SAMPLING DESIGN}

Sampling Unit: It deals with the people to be surveyed the researcher must define the target

Sampling Size: The sample size of the specific study is 100 as this is a particular sector of company.

Sampling Procedure: Sample random sampling technique is employed for selection of 50 respondents from the total population pool.

Simple Random Sampling: The personal judgment method has employed for the selection of sampling, the simple random sampling is the simplest form of probability sampling to collect the information from customer.

\subsection{METHODOLOGY}

The researcher is used data, which has collected in two ways such as primary and secondary data.

Primary Data: Primary data is gathers through questionnaire, schedule interview.

Secondary Data: The secondary data has collected through structured account statement of the concern, books, journals, magazines, newspaper.

Statistical Tools Used: Percentage method is used for analysis of data. The result of the research is presented through tables.

\section{SCOPE OF THE STUDY}

The area of study is limited to the segment selected within SALEM district. This study is mainly confined to the customer satisfaction only.

\section{STATEMENT OF THE PROBLEM}

Today, a lot of masla products are producing companies have started manufacturing masala products all over the world. One of the most popular or famous was Sakthi masala product. This Trading Company produce masala product like pickles, Ghee, oil etc., For large scale under the brand name of Sakthi. It is essential to study about the customer satisfaction of Sakthi Masala product, this interest makes the researcher to take up the research study entitled. 


\section{LIMITATIONS OF THE STUDY}

The primary data is collected through a structured questionnaire and the sample size has limited only 50 respondents.

\section{ANALYSIS AND INTERPREATION}

Table 1: CLASSIFICATION OF TABLE ON THE BASIS OF GENDER

Source: primary Data

\begin{tabular}{|l|l|l|l|}
\hline S.No & \multicolumn{1}{|c|}{ Genders } & \multicolumn{1}{c|}{$\begin{array}{c}\text { No. of } \\
\text { Respondents }\end{array}$} & \multicolumn{1}{c|}{ Percentage } \\
\hline 1 & Male & 20 & $20 \%$ \\
\hline 2 & Female & 80 & $80 \%$ \\
\hline & Total & 100 & $100 \%$ \\
\hline
\end{tabular}

Interpretation: From the above table is inferred that out of the 100 respondents, $80 \%$ of the respondents are female and $20 \%$ of the respondent are male buyer. The above analysis is showing $80 \%$ of the respondents are female buyer.

Table 2: CLASSIFICATION OF TABLE ON THE BASIS OF MARITAL STATUS

Source: Primary Data

\begin{tabular}{|l|l|l|l||}
\hline S.No & \multicolumn{1}{|c||}{ Marital status } & $\begin{array}{c}\text { No. of } \\
\text { Respondents }\end{array}$ & Percentage \\
\hline 1 & Married & 60 & $60 \%$ \\
\hline 2 & Un Married & 40 & $40 \%$ \\
\hline & Total & 100 & $100 \%$ \\
\hline
\end{tabular}

Interpretation: From the above table inferred that out of the 100 respondents, $60 \%$ of the respondents are married and $40 \%$ of the respondents are unmarried. The above analysis is showing $60 \%$ of the Sakthi masala product users are married persons.

Table 3: CLASSIFICATION OF TABLE ON THE BASIS OF OCCUPATIONAL STATUS

Source: Primary Data

\begin{tabular}{|l|l|l|l||}
\hline S. No & $\begin{array}{c}\text { Occupational } \\
\text { Status }\end{array}$ & $\begin{array}{c}\text { No. of } \\
\text { Respondents }\end{array}$ & Percentage \\
\hline 1 & House wife & 36 & $36 \%$ \\
\hline 2 & Employee & 44 & $44 \%$ \\
\hline 3 & Business & 20 & $20 \%$ \\
\hline & Total & 100 & $100 \%$ \\
\hline
\end{tabular}

Interpretation: From the above table inferred that out of the 100 respondents, nearly $44 \%$ of the respondents are Employee, 36\% of the respondents are house wife and 20\% of the respondents are business persons. The above analysis is showing employee and house wife most interest using Sakthi Masala product. 
Table 4: CLASSIFICATION OF TABLE ON THE BASIS OF USING MASALA

Source: Primary Data

\begin{tabular}{|l|l|l|l||}
\hline S. No. & Using Masala & \multicolumn{1}{c||}{$\begin{array}{c}\text { No. of } \\
\text { Respondents }\end{array}$} & \multicolumn{1}{||}{ Percentage } \\
\hline 1 & Vegetarian & 22 & $22 \%$ \\
\hline 2 & Non- vegetarian & 14 & $14 \%$ \\
\hline 3 & Both & 64 & $64 \%$ \\
\hline & Total & 100 & $100 \%$ \\
\hline
\end{tabular}

Interpretation: From the above table inferred that out of the 100 respondents, $64 \%$ of the respondents are using both vegetarian and non-vegetarian masala, 22\% of the respondents are vegetarian only, $14 \%$ of the respondents are Non-vegetarian user only. The above analysis is showing that $64 \%$ of the respondents are using vegetarian and Non-vegetarian masala.

Table 5: CLASSIFICATION OF TABLE ON THE BASIS OF MOST IMPORTANT ITEMS OF PURCHASE SAKTHI MASALA PACKET

Source: Primary data

\begin{tabular}{|l|l|l|l||}
\hline S. No. & \multicolumn{1}{|c||}{ Purchase } & \multicolumn{1}{c||}{$\begin{array}{c}\text { No. of } \\
\text { Respondents }\end{array}$} & Percentage \\
\hline 1 & Chilly powder & 30 & $30 \%$ \\
\hline 2 & Coriander powder & 12 & $12 \%$ \\
\hline 3 & Turmeric powder & 35 & $35 \%$ \\
\hline 4 & Chicken masala & 20 & $20 \%$ \\
\hline 5 & Other masala user & 03 & $03 \%$ \\
\hline & Total & 100 & $100 \%$ \\
\hline
\end{tabular}

Interpretation: The above table shows that out of the 100 respondents, $35 \%$ of the respondents are turmeric powder purchasing, $30 \%$ of the respondents are chilly powder purchasing, $20 \%$ of the respondents are chicken masala purchasing, $12 \%$ of the respondents are coriander powder purchasing, 3\% of the respondents are used to others masala purchasing. The above analysis is showing that $35 \%$ of the respondents are expressed positive approach towards this brand especially turmeric powder purchasing.

Table 6: CLASSIFICATION OF TABLE ON THE BASIS OF OPINION REGARDING PRICE LEVEL OF SAKTHI MASALA PRODUCT

Source: Primary data

\begin{tabular}{|l|l|c|l||}
\hline S. No. & Opinion of price & $\begin{array}{c}\text { No. of } \\
\text { respondents }\end{array}$ & \multicolumn{1}{|c|}{ Percentage } \\
\hline 1 & High & 06 & $6 \%$ \\
\hline 2 & Reasonable & 78 & $78 \%$ \\
\hline 3 & Low & 16 & $16 \%$ \\
\hline & Total & 100 & $100 \%$ \\
\hline
\end{tabular}


Interpretation: From the above table inferred that out of the 100 respondents nearly $78 \%$ of the respondents are saying reasonable price, $16 \%$ of the respondents are price is low and $6 \%$ of the respondents are saying high price. The above analysis inferred that mostly $78 \%$ of the respondents are satisfied with reasonable price for sakthi masala product.

Table 7: CLASSIFICATION OF TABLE ON THE BASIS OF SATISFACTION LEVEL OF FLAVOUR OF SAKTHI MASALA PRODUCTS

Source: Primary data

\begin{tabular}{|l|l|l|l||}
\hline S.No. & \multicolumn{1}{|c|}{$\begin{array}{c}\text { Satisfaction level of } \\
\text { flavour }\end{array}$} & $\begin{array}{c}\text { No. of } \\
\text { respondents }\end{array}$ & Percentage \\
\hline 1. & Highly satisfied & 58 & $58 \%$ \\
\hline 2. & Satisfied & 36 & $36 \%$ \\
\hline 3. & Moderately Satisfied & 6 & $6 \%$ \\
\hline 4. & Dissatisfied & 00 & $0 \%$ \\
\hline 5. & Highly Dissatisfied & 00 & $0 \%$ \\
\hline & Total & 100 & $100 \%$ \\
\hline
\end{tabular}

Interpretation: From the above table inferred that out of the 100 respondents nearly $58 \%$ of the respondents are highly satisfied smell of Sakthi masala products, 36\% of the respondents are satisfied, $6 \%$ of the respondents are moderately satisfied.

\section{FINDINGS}

- Majority of $80 \%$ of the respondents are Female user belong the Sakthi Masala Product.

- Nearly $60 \%$ of the Sakthi Masala Products users are married persons.

- Nearly $44 \%$ of the respondents are employee and house wife most interest in use in Sakthi Masala Product.

- Majority of $64 \%$ of the respondents are using vegetarian and non-vegetarian masala products.

- Nearly $35 \%$ of the respondents are purchasing turmeric product.

- Nearly $34 \%$ of the respondents are preferred to buy $50 \mathrm{~g}$ packet.

- Mostly $78 \%$ of the respondents are satisfied and price is reasonable.

- Majority of 58\% of the respondents are highly satisfied smell of Sakthi Masala product.

- Majority of $62 \%$ of the respondents are highly satisfied taste of Sakthi Masala Product.

- Majority of $70 \%$ of the respondents are highly satisfied to packing of the Sakthi Masala Product.

\section{SUGGESTIONS}

Sakthi Masala Product at present so many varieties available. But, they do not have customer awareness about masala produces so, if they provide awareness to their customer they will get more customer.

Based on my analysis Sakthi Masala Producer could provide credit facilities to their customers. They Sakthi Masala company need more advertisement about their product availability. 


\section{CONCLUSION}

This project entitled that customer satisfaction of Sakthi Masala Products. The overall analyse of the study indicate that at presents so many varieties of products available even the customer were satisfied product smell, taste, quality, cost, packing of the sakthi masala products in SALEM District.

\section{REFERENCES}

[1] Kothari. C.R, (2007) Research Methodology, New Age International Publication, New Dhelhi.

[2] Sheriekar. S.A, Marketing Management, Himalaya Publishing House, 13th revised edition.

[3] Regi, S. B. \& S, A. R. G. (2014). "A DESCRIPTIVE STUDY ON THE ROLE OF CONSUMER PSYCHOLOGY AND BEHAVIOUR IN PRODUCT PURCHASING”. Indian Streams Research Journal, 3.

[4] Ganesan. S\& Rajanbabu. R, "consumer satisfaction in processed spices products" jms.nonolympictimes.org/Articles/7.pdf.

[5] www.sakthimasala.com. 